\title{
IgG subclasses compared in maternal and cord serum and breast milk
}

\author{
A Gasparoni, A Avanzini, F Ravagni Probizer, G Chirico, G Rondini, F Severi
}

\begin{abstract}
Total and specific IgG subclass antibodies against 14 pneumococcal capsular polysaccharide antigens on the cord serum from 11 healthy term infants at birth and on serum from their mothers at delivery were evaluated. The same evaluation was performed five days after delivery on the serum and the milk obtained from the six mothers who were breast feeding their infants. Mean neonatal: maternal serum ratio of total $\mathbf{I g G}_{1}$ was significantly higher than the ratios of total $\mathbf{I g G}_{2}$, $\mathrm{IgG}_{3}$, and $\mathrm{IgG}_{4}$ and higher than the ratios of pneumococcal IgG subclass antibodies. Total $\mathbf{I g G}_{3}$ and $\mathbf{I g G}_{4}$ ratios were higher than the specific antibody ratios of the same IgG subclass. Type 1 and type 14 IgG $_{1}$ antibodies were the highest antipneumococcal ratios.

Although the maternal milk:serum ratios of total IgG subclasses were very low, significant amounts of specific antibodies were found in the milk, at about half the concentration observed in mother's serum.
\end{abstract}

Maternal IgG, transferred across the placenta to the fetus during intrauterine life, represents an important component of the neonatal immunological defence mechanisms against infection. ${ }^{1}$ $\mathrm{IgG}_{1}$ subclass antibodies are transferred at a greater extent than $\operatorname{IgG}_{2}, \mathrm{IgG}_{3}$, and $\mathrm{IgG}_{4}$ due to an active transport process. ${ }^{2}$

Chudwin et al reported that the maternalfetal transfer of total IgG was higher than the transfer of the $7 \mathrm{~F}$ pneumococcal polysaccharide specific $\operatorname{IgG} .^{3}$ Soto et al showed that higher concentrations of neutralising antibodies to measles, mumps, and rubella viruses were present in cord sera than in paired maternal sera. ${ }^{4}$ On the other hand, other researchers could not find significant differences between maternal:fetal ratio of total IgG and specific IgG against either group B streptococcus or Haemophylus influenzae (polysaccharide antigens) or tetanus toxin. 56

The aim of the present study was to evaluate the maternal-fetal transfer of total and specific IgG subclass antibodies against 14 pneumococcal capsular polysaccharide antigens. We also evaluated the same antibodies in the milk of mothers who were breast feeding their infants.

Patients and methods

We studied 11 healthy term infants with birth weight from 2760 to $4050 \mathrm{~g}$ (mean $3440 \mathrm{~g}$ ) and gestational age from 39 to 41 weeks (mean $40 \cdot 2$ weeks), and their mothers, aged 18 to 38 years (mean 32 years).
A sample of cord blood was obtained from all infants at birth and a sample of venous blood from all mothers. Five days after delivery a sample of venous blood and of milk were obtained from the six mothers who were breast feeding their infants.

Blood samples were allowed to clot at room temperature and were then centrifuged; aliquots of serum were frozen at $-20^{\circ} \mathrm{C}$ until analysis. Samples of breast milk were centrifuged at 2000 $g$ for 10 minutes and the upper lipid and lower cellular fractions were discarded; a second centrifugation at $4500 \mathrm{~g}$ was then performed for 30 minutes and the middle fraction was collected and frozen at $-20^{\circ} \mathrm{C}$ until analysis.

\section{IgG SUBCLASS DETERMINATION}

Total IgG subclasses were quantified by radial immunodiffusion as previously described. ${ }^{7}$ Briefly, monoclonal antibodies (Umpath) to IgG $_{1}$ (clone JL512), IgG 2 (clone GOM1), IgG (clone 2G4), and $\mathrm{IgG}_{4}$ (clones RJ4+GB7B) were added to agarose $1 \%$ in $0.1 \mathrm{M}$ barbitone buffer $\mathrm{pH} 8.6$ containing $6 \%$ polyethyleneglycol (PEG 3000, Fluko) at the concentrations of $0.2 \%, 1.4 \%, 0.3 \%$, and $0.5 \%$, respectively. Samples to be tested were diluted $1 / 10$ in barbitone buffer for IgG $\mathrm{Ig}_{1}$ and $\mathrm{IgG}_{2}$ and $1 / 2$ for $\mathrm{IgG}_{3}$ and $\mathrm{IgG}_{4}$. Plates were left at $4^{\circ} \mathrm{C}$ for 48 hours, washed overnight in barbitone buffer containing $2 \%$ glutaraldehyde, dried, and stained with Comassie brilliant blue. Results were interpolated from a standard curve constructed using a pool of normal sera calibrated against World Health Organisation reference serum (67/97). Lower sensitivity limits were 0.017 $\mathrm{g} / \mathrm{l}$ for $\mathrm{IgG}_{1}, 0.045 \mathrm{~g} / \mathrm{l}$ for $\mathrm{IgG}_{2}, 0.01 \mathrm{~g} / \mathrm{l}$ for $\mathrm{IgG}_{3}$, and $0.064 \mathrm{~g} / \mathrm{l}$ for $\mathrm{IgG}_{4}$, respectively.

SPECIFIC IgG SUBCLASSES DETERMINATION

Four polyvinyl chloride microtitre plates (M24A Dynatech Laboratories, Virginia) were coated with the capsular polysaccharide types: $1,2,3,4,6 \mathrm{~A}, 7 \mathrm{~F}, 8,9 \mathrm{~N}, 12 \mathrm{~F}, 14,18 \mathrm{G}, 19 \mathrm{~F}$, $23 \mathrm{~F}$, and 25 at the concentration of $5 \mu \mathrm{g} / \mathrm{ml}$ in carbonate-bicarbonate buffer $\mathrm{pH} 9 \cdot 6$, incubating for three hours at $37^{\circ} \mathrm{C}$ and overnight at $4^{\circ} \mathrm{C}$. After three washings, $100 \mu \mathrm{l}$ of the samples to be tested were diluted $1 / 50$ in bovine serum albumin (BSA) $2 \%$ in phosphate buffered saline (PBS), in duplicate, and the plates were incubated for two hours at $37^{\circ} \mathrm{C}$. After three washings, $100 \mu \mathrm{l}$ of IgG subclass specific monoclonal antibodies (clones JL512, GOM1, ZG4, RJ4; Sewards Laboratory) diluted $1 / 1000$ in BSA $2 \%$ in PBS were added. After two hours at 
$37^{\circ} \mathrm{C}$ and three washings, $100 \mu \mathrm{l}$ of peroxidase conjugated rabbit antimouse Ig (Dako) diluted $1 / 500$ in PBS $15 \%$ calf serum were added and plates incubated and washed as above. Then $100 \mu \mathrm{l}$ of freshly prepared substrate solution (50 mg o-phenylenediamine with $25 \mathrm{ml}$ phosphate buffer pH 6 and $12.5 \mu l \mathrm{H}_{2} \mathrm{O}_{2}, 2 \mathrm{~N}$ ) were added to each well and after 20 minutes absorbance was recorded using Titertek Multiskan Photometer (Flow Laboratories) at $492 \mathrm{~nm}$. Results were expressed as percentage of a positive pooled human serum reference. This method is much more sensitive than radial immunodiffusion.

\section{STATISTICAL ANALYSIS}

This was carried out by the two way analysis of variance, after logarithmic transformation of ratios, and by the Duncan's multiple range test, to evaluate the difference between mean neonatal:maternal serum ratios and maternal milk:serum ratios of specific IgG subclass antibody concentrations or of total IgG subclass concentrations. Analyses were performed with the Biometrics package (Lionheart).

\section{Results}

Mean (SD) for cord and maternal serum concentrations of total IgG subclasses are reported in table 1 .

Mean (SD) neonatal:maternal ratios of serum concentrations of IgG subclasses and specific IgG subclass antibodies against pneumococcal capsular polysaccharide antigens are given in table 2. No significant differences were found between mother's specific IgG subclass concentrations before and at five days after delivery.

The two way analysis of variance, performed after logarithmic transformation of ratios, showed a significant difference within the subjects $(F=7.32 ; \mathrm{p}<0.0001)$ and within the ratios $(F=2.41 ; \mathrm{p}<0.0001)$. The standard error of the whole table was $0 \cdot 2461$.

Table 1 Cord and maternal serum concentrations of total IgG subclasses. Results are expressed in $\mathrm{g} / \mathrm{l}$ and reported as mean $(S D)$

\begin{tabular}{lllll}
\hline & $I g G_{1}$ & $I g G_{2}$ & $I g G_{3}$ & $I g G_{4}$ \\
\hline Cord & $7.82(2.93)$ & $2.54(0.91)$ & $0.42(0.21)$ & $0.59(0.22)$ \\
Mother & $4.87(2.17)$ & $3.33(1.09)$ & $0.47(0.31)$ & $0.52(0.20)$ \\
\hline
\end{tabular}

Table 2 Neonatal:maternal serum ratios of total and specific IgG subclass antibodies against pneumococcal capsular polysaccharide antigens. Results are expressed as mean (SD)

\begin{tabular}{lllll}
\hline Types & $I g G_{1}$ & $I g G_{2}$ & $I g G_{3}$ & $I g G_{4}$ \\
\hline 1 & $1.07(0.32)$ & $0.73(0.16)$ & $0.82(0.28)$ & $0.80(0.31)$ \\
2 & $0.45(0.41)$ & $0.54(0.21)$ & $0.35(0.29)$ & $0.37(0.36)$ \\
3 & $0.49(0.60)$ & $0.62(0.36)$ & $0.51(0.44)$ & $1.31(2.09)$ \\
4 & $0.74(0.54)$ & $0.87(0.39)$ & $0.87(0.97)$ & $0.65(0.43)$ \\
6 & $0.80(0.76)$ & $0.63(0.32)$ & $0.45(0.35)$ & $0.44(0.68)$ \\
7 & $0.58(0.31)$ & $1.00(1.05)$ & $0.50(0.32)$ & $0.56(0.37)$ \\
8 & $0.66(0.45)$ & $0.52(0.26)$ & $0.47(0.41)$ & $0.31(0.31)$ \\
9 & $0.47(0.38)$ & $0.56(0.28)$ & $0.48(0.48)$ & $0.36(0.42)$ \\
12 & $0.12(0.27)$ & $0.51(0.49)$ & $0.17(0.30)$ & $0.33(0.4)$ \\
14 & $0.99(0.40)$ & $0.67(0.19)$ & $0.51(0.41)$ & $0.36(0.31)$ \\
18 & $0.61(0.41)$ & $0.55(0.25)$ & $0.26(0.37)$ & $0.47(0.52)$ \\
19 & $0.50(0.43)$ & $0.65(0.25)$ & $0.58(0.40)$ & $0.59(0.36)$ \\
23 & $0.43(0.49)$ & $0.64(0.31)$ & $0.63(0.87)$ & $0.43(0.30)$ \\
25 & $0.51(0.26)$ & $0.74(0.28)$ & $0.46(0.25)$ & $0.56(0.29)$ \\
Total IgG & $1.66(0.43)$ & $0.78(0.19)$ & $0.89(0.46)$ & $1.17(0.45)$ \\
\hline
\end{tabular}

Table 3 Maternal milk: serum ratios of total and specific antipneumococcal IgG subclass antibodies. Results are expressed as mean (SD)

\begin{tabular}{lllll}
\hline Types & $I g G_{1}$ & $I g G_{2}$ & $I g G_{3}$ & $I g G_{4}$ \\
\hline 1 & $0.13(0.08)$ & $0.11(0.07)$ & $0.37(0.33)$ & $0.28(0.24)$ \\
2 & $0.72(0.58)$ & $0.18(0.14)$ & $0.86(1.05)$ & $0.66(0.47)$ \\
3 & $0.37(0.33)$ & $0.13(0.21)$ & $0.45(0.11)$ & $0.48(0.46)$ \\
4 & $0.48(0.43)$ & $0.34(0.38)$ & $2.67(2.33)$ & $1.20(1.20)$ \\
6 & $0.44(0.51)$ & $0.34(0.27)$ & $1.48(0.89)$ & $1.49(1.27)$ \\
7 & $0.64(0.71)$ & $0.11(0.12)$ & $0.78(0.66)$ & $0.78(0.57)$ \\
8 & $0.46(0.66)$ & $0.20(0.15)$ & $0.60(0.70)$ & $0.76(0.53)$ \\
9 & $0.96(1.74)$ & $0.29(0.17)$ & $0.42(0.46)$ & $1.09(0.84)$ \\
12 & $0.45(0.48)$ & $0.34(0.45)$ & $0.37(0.36)$ & $2.04(2.95)$ \\
14 & $0.15(0.25)$ & $0.19(0.14)$ & $1.19(1.90)$ & $1.01(0.67)$ \\
18 & $0.15(0.03)$ & $0.07(0.09)$ & $0.75(0.85)$ & $0.75(0.96)$ \\
19 & $0.27(0.29)$ & $0.34(0.34)$ & $0.71(0.67)$ & $0.83(0.59)$ \\
23 & $0.98(1.60)$ & $0.65(0.71)$ & $0.81(1.08)$ & $1.27(0.59)$ \\
25 & $0.12(0.08)$ & $0.36(0.25)$ & $0.73(0.72)$ & $0.99(0.57)$ \\
Total IgG & $<0.0034$ & $<0.0066$ & $<0.022$ & $<0.18$ \\
\hline
\end{tabular}

The following evaluation by the Duncan's multiple range test $(p<0.01)$ showed that mean total IgG $_{1}$ neonatal:maternal serum ratio was significantly higher than all the other total and specific IgG subclass ratios; total $\mathrm{IgG}_{3}$ and $\mathrm{IgG}_{4}$ ratios were significantly higher than the specific antibodies of the same subclass (except types 1 and $4 \mathrm{IgG}_{3}$ and type $3 \mathrm{IgG}_{4}$ ); type 1 and $14 \mathrm{IgG}_{1}$ neonatal:maternal serum ratios were significantly higher than the other $I_{g G_{1}}$ specific ratios (except types 4 and 6 ratio). Furthermore, type 1 specific $\operatorname{IgG}_{1}$ ratio was higher than type $1 \mathrm{IgG}_{2}$ ratio; type $14 \mathrm{IgG}_{1}$ ratio was higher than type 14 $\mathrm{IgG}_{3}$ and $\mathrm{IgG}_{4}$ ratio.

Mean (SD) maternal milk:serum ratios of total and specific antipneumococcal IgG subclass antibodies, evaluated on maternal serum obtained five days after delivery, are reported in table 3. Total IgG subclass concentrations in the milk were always below the lower sensitivity limits of the assay.

The two way analysis of variance, performed after logarithmic transformation of ratios, showed a significant difference within the subjects $(F=18.7 ; \mathrm{p}<0.0001)$ and within the ratios $(F=2.58 ; \mathrm{p}<0.0001)$. The standard error of the whole table was 0.4329 .

The following evaluation by the Duncan's multiple range test $(p<0.01)$ showed that the maternal milk:serum ratio of types 4,6 , and 14 $\mathrm{IgG}_{3}$ and types $4,6,9,12,14,23$, and $25 \mathrm{IgG}_{4}$ antibodies were higher than the other ratios of specific antibodies.

As concentrations of total IgG in milk were undetectable, maternal milk:serum ratios of total IgG have not been included in the statistical analysis.

\section{Discussion}

Maternal IgG transfer to the fetus across the placenta begins at the 16th week of gestation, and is mainly completed during the last six weeks of gestation. ${ }^{8}$ The finding of a higher transport rate of $\operatorname{IgG}_{1}$, as compared with $\operatorname{IgG}_{2}$, $\mathrm{IgG}_{3}$, and $\mathrm{IgG}_{4}$, which was previously reported and is confirmed by our study, could be related to a higher trophoblastic receptor affinity for the $I_{g G} F c$ fragment than for the $F c$ fragment of other subclasses ${ }^{9}$ and to an early selective capacity of synthesis by the infant. ${ }^{10}$ As for specific IgG transfer, it is controversial whether the neonatal:maternal serum ratio of specific 
antibodies is higher, ${ }^{4}$ similar, ${ }^{36}$ or reduced ${ }^{5}$ as compared with that of total antibodies.

In the present study we found lower neonatal: maternal serum ratios of specific than total $I_{g G}, I g G_{3}$, and $I g G_{4}$ subclasses. Our results are in agreement with those reported by Chudwin $e t$ $a l$, who evaluated the transfer of total and specific antibodies against $7 F$ type pneumococcal antigen, although with no differentiation in IgG subclasses. ${ }^{3}$

At variance with previous reports, ${ }^{11} 12$ we could not observe a restriction of antipneumococcal polysaccharide antigen $\operatorname{IgG}$ to the $\mathrm{IgG}_{2}$ subclass. We found that neonatal:maternal serum ratios of $I_{1 g}$ subclass antibodies against types 1 and 14 antigens were higher than ratios of other specific IgG subclass antibodies. As types 1 and 14 pneumococcal polysaccharide antigens are more immunogenic than other types, ${ }^{13}$ we can hypothesise that a greater immunogenicity may be important for the modulation of transplacental transfer of antibodies.

Although the maternal milk:serum ratios of IgG subclasses were very low, in agreement with a previous study which reported that less than the $3 \%$ of maternal serum IgG is present in the milk, ${ }^{14}$ we found significant amounts of specific antibodies in the milk (particularly within the $\operatorname{IgG}_{3}$ and $\operatorname{IgG}_{4}$ subclasses), at about half the concentration observed in the mother's serum. This finding could be related to a selective secretion and/or to a local production of antibodies by milk cells. ${ }^{15}$ The presence of specific antibodies in breast milk may be considered as a compensatory factor for the reduced maternal-neonatal transfer of specific IgG subclass antibodies.
We are very thankful to Mr Attilio Ascione for his technical assistance and to nurses Anna MariaGrasso and Fara Pilo for help with blood sampling.

1 Pitcher-Wilmott RW, Hindocha P, Wood CBS. The placental transfero of IgG subclasses in human pregnancy. Clin Exp Immunol 1980;41:404-8.

2 Oxelius VA. IgG subclass levels in infancy and childhood. Acta Paediatr Scand 1979;68:23-7.

3 Chudwin DS, Wara D, Schiffman G, Artrip SG, Ammann AJ. Maternal-fetal transfer of pneumococcal capsula polysaccharide antibodies. Am fo Dis Child 1985;139: 378-90.

4 Soto H, Albrecht P, Reynolds DW, Stagno S, Ennis FA. Transfer of measles, mumps and rubella antibodies from mother to infant. Am $\mathcal{F}$ Dis Child 1979;133:1240-5.

5 Einhorn MS, Granoff DM, Nahm MH, Quinn A, Shackleford PG. Concentrations of antibodies in paired maternal and infant sera: relationship to IgG subclass. $\mathcal{f}$ Pediatr 1987; 111:783-8.

6 Baker CJ, Webb BJ, Kasper DL, Yow MD, Beachler CW. The natural history of group $B$ streptococcal colonization in The natural history of group B streptococcal colonization in the pregnant woman and

7 Plebani A, Ugazio AG, Avanzini MA, et al. Serum IgG subclass concentrations in healthy subjects at different age: age-normal percentile charts. Eur $\mathcal{f}$ Pediatr 1989;149: $164-7$

8 Stiehm ER. Fetal defence mechanisms. Am $\mathcal{f}$ Dis Child 1975;129:438-43.

9 McNabb T, Koh TY, Dorrington KJ, Painter RH. Structure and function of immunoglobulin domains. V. Binding of immunoglobulin $G$ and fragments to placental membrane preparations. F Immunol 1976;117:882-8.

10 Oxelius VA, Svenningsen NW. IgG subclass concentrations in preterm neonates. Acta Paediatr Scand 1984:73:626-30.

11 Hammarstrom $L$ Granstrom M Mollby $R$, Oxelius VA Person MA ' Smith CIE Ontegny of IoG antibodies Persson MAA, Smith CIE. Ontogeny of IgG $_{2}$ antibodies against $S$ aureus techoic acid in normal and immun

12 deficient children. Acta Paediatr Scand 1985;74:126-30. to pneumococcal polysaccharides. Clin Exp Immunol 1986; to pneumococ

13 Roberton DM, Bjorkander J, Henrichsen J, Soderstrom T, Hanson $\mathrm{LA}$. Enhanced $\mathrm{IgG}_{1}$ and $\mathrm{IgG}_{3}$ responses to pneumococcal polysaccharides in isolated $\operatorname{IgA}$ deficiency. Clin Exp Immunol 1989;75:201-5.

14 McClelland DBL, McGrath J, Samson RR. Antimicrobia factors in human milk: studies of concentration and transfer to the infant during the early stages of lactation. Acta Paediatr Scand 1978;67(suppl 271):1-20.

15 Keller MA, Gendreau-Reid L, Heiner DC, Rodriguez A, Short $\mathrm{JA}$. $\mathrm{IgG}_{4}$ in human colostrum and human milk: continued local production or selected transport from serum. Acta Paediatr Scand 1988;77:24-9. 